\title{
Estetización de la memoria: formación y espacios de lo político*
}

// An aestheticization of memory. Political training and spaces

//Estetização da memória: formação e Revista Colombiana de Educación, N. 62. Primer semestre de 2012 espaços do político

Investigaciones Bogotá, Colombia.

\author{
Vladimir Olaya Gualteros** \\ Mariana lasnaia Simbaqueba***
}

\begin{abstract}
El presente trabajo hace parte del macro proyecto de investigación Memorias de la violencia y formación ético política en jóvenes maestros en Colombia, llevado a cabo por el grupo de investigación en Educación y Cultura Política de la Universidad Pedagógica Nacional y financiado por el Centro de investigaciones de la Universidad Pedagógica Nacional. A su vez, es parte del trabajo de investigación Memoria, arte y violencia, presentado como tesis de maestría elaborada por Mariana Simbaqueba, cuyo director es Vladimir Olaya.

Magister en Educación de la Universidad Pedagógica Nacional y licenciado en Lingüística y Literatura de la Universidad Distrital Francisco José de Caldas. Vinculado al grupo de investigación Educación y Cultura Política. Correo electrónico: Vlado2380@gmail.com

Licenciada en Educación Básica con énfasis en Educación Artística de la Universidad Distrital Francisco José de Caldas. Adelanta la Maestría en Educación de la Universidad Pedagógica Nacional. Vinculada al grupo de investigación Educación y Cultura Política. Correo electrónico: iasna1@hotmail.com
\end{abstract}

\section{Resumen}

El presente texto intenta analizar la manera en que algunas obras de arte se edifican a partir de la memoria y desde allí constituyen espacios de lo político y de formación de los individuos. En este orden de ideas, el texto inicia presentando algunas relaciones entre memoria, arte y formación. Luego se introduce en la reflexión acerca de la manera como distintas obras de arte se constituyen en un espacio de lo político. Por último, se aproxima a las obras de Erika Diettes, Río abajo y Sudarios, observando en ellas la forma como edifican espacios de lo político y generan procesos de formación en los individuos. Así, el artículo parte de una premisa fundamental: el trabajo artístico de Erika Diettes ${ }^{1}$ se constituye en una intervención, acontecimiento que elabora un espacio de lo político que incide en las maneras de comprender el mundo y los otros, posibilitando la formación de otras percepciones que van más allá de un ejercicio de representación de la violencia y el dolor de hombres y mujeres afectados por la violencia.

1 Fotógrafa, artista visual, nacida en Cali, Colombia en 1978. La memoria, la violencia, la desnudez y la muerte son temas recurrentes en sus obras. En sus trabajos se articulan la fragilidad del hombre y la historia contemporánea. Sus elaboraciones han sido expuestas en importantes escenarios a nivel nacional, tales como los Museos de Arte Moderno de Bogotá, Cali, Medellín, Barranquilla, el Museo de Arte Contemporáneo de Neiva, el Museo de la Universidad de Antioquia, el Museo Nacional de Colombia, el Museo Iglesia Santa Clara y, a nivel internacional, en el Museo de Arte Contemporáneo de Santiago de Chile, el Centro Cultural Recoleta en Buenos Aires y De Santos Gallera, Houston- Estados Unidos, entre otros.

\section{Palabras Clave}

Memoria, arte, violencia política, formación. 


\section{Abstract}

This paper attempts to analyze the way some art works are built from memory setting up political and education rooms for individuals. In this vein, this text begins with some relationships among memory, art and education; then a reflection on how several art works are a politic room; and finally, an approach of works by Erika Diettes, Río abajo y Sudarios, watching the way they build political rooms and generate education processes for individuals. Thereby, this paper begins from a basic assumption: the artwork by Erika Diettes is mediation, i.e. an event producing a politic room that influence on ways to understand the world and the others, enabling the formation of other perceptions beyond an exercise of representation of violence and pain in men and women affected by violence.

\section{Keywords}

Memory, art, political violence, education.

\section{Resumo}

O Presente texto procura analisar como algumas obras de arte são construídas a partir da memória, constituindo-se, a partir daí, em espaços do político e de formação de indivíduos. Nesse sentido, o texto inicia apresentando algumas relações entre arte, memória e formação. Logo, se introduz na reflexão sobre a forma como distintas obras de arte se constituem como um espaço do político. Por último, aborda as obras de Erika Diettes: Rio

Abaixo e Sudários, nelas observando a forma como constroem espaços políticos e geram processos de formação de indivíduos. Assim, o artigo parte de uma premissa fundamental: o trabalho artístico de Erika Diettes se constitui como uma intervenção, acontecimento que elabora um espaço do político que incide sobre as maneiras de compreender o mundo e os outros, possibilitando a formação de outras percepções que vão além

de um exercício de representação da violência e da dor de homens e mulheres por ela afetados.

\section{Palavras chave}

Memória, arte, violência, formação. 


\section{Presentación}

Yo, como tú, he intentado con todas mis fuerzas combatir el olvido. Como tú, he olvidado. Como tú, he querido tener una memoria inconsolable, una memoria de sombras y de piedra. He luchado todos los días, con todas mis fuerzas, contra el horror de no comprender del todo el por qué del recordar. Como tú, he olvidado. ¿Por qué negar la evidente necesidad de la memoria?

Hiroshima Mon Amour (1959) Alain Resnais

Las expresiones artísticas, como lo afirma Elsa Blair, son reflejo de una sociedad, de las relaciones que esa sociedad establece consigo misma a través de diferentes procesos o fenómenos sociales (Blair, 2005, p.147). En este sentido, dar cuenta de la complejidad del fenómeno de la violencia requiere, por supuesto, una mirada a las formas en que los sujetos la representan, es decir, su dimensión simbólica.

Toda acción humana es acción simbólica en sí misma dado que significa algo. Los elementos simbólicos, compuestos por significaciones (ideas, abstracciones o representaciones de juicios o creencias) componen tramas de sentido a partir de las cuales se entiende, ordena y construye la propia vida. De tal for$\mathrm{ma}$, ante la vivencia del hecho violento, los sujetos y las sociedades desarrollan mecanismos de ritualización, simbolización y tramitación que les permiten comprender lo acontecido, asimilar las pérdidas y tramitar los duelos y memorias de los hechos vividos. Uno de estos mecanismos es el arte.

Según algunos teóricos hay en el arte un esfuerzo por "reinstalar el sufrimiento de otros en la esfera pública" (Uribe, 1999, p. 284), lo que a su vez algunos artistas relacionan con la posibilidad de lograr, a través de la obra, activar mecanismos proyectivos, los cuales permiten a los sujetos reflejarse en lo otro, generando cuestionamientos éticos desde lo estético, visibilizando el fenómeno [la violencia] y sus campos de significación. Aunado a ello, el arte contemporáneo ha abordado el conflicto colombiano desde lo estético con la intención clara de "generar procesos de recuperación de distintos tipos de memoria, al aludir a hechos y comportamientos sobre los que es necesario hacer conciencia para mirar hacia delante y detener el círculo irreflexivo de repeticiones de la historia de violencia que marcó la segunda mitad del siglo XX y que signa los comienzos del siglo XXI en nuestro país" (Arango, 2004, p.17).

Pese a este esfuerzo y a las visibilidades de hechos históricos en algunas obras de arte, la pregunta que sugieren estos trabajos es: ¿cómo la obra de arte y las propuestas estéticas reconstruyen algunas formas de la memoria, la utilizan y la integran en sus construcciones, sobre todo en contextos de violencia política como los vividos en Colombia? Si bien esta pregunta es de largo alien- 
to, intentaremos esbozar algunos acercamientos que permitan comprender la manera en que algunas obras de arte sobrepasan la idea de monumento histórico y edifican en ellas mismas los sentidos elaborados desde diversas memorias y se constituyen como espacios de lo político.

\section{Memoria, arte, política y formación}

Entendemos la obra de arte como construcción simbólica en la que se refleja y comprime el hacer del mundo social. En este sentido, la obra reconstruye e instala un mundo que, si bien nuevo, está ligado con terrenos culturales, sociales y políticos. Es decir, reconstituye los espacios reelaborándolos, significándolos, pero a su vez sustrayéndose, en muchos casos, de los mismos. Las obras de arte, sobre todo aquellas a las que podemos llamar contemporáneas, se alejan de una mirada referencial a una realidad. Su propósito sobrepasa la elaboración de un referente preciso y desde la perspectiva del autor emana una visión que se dirige al otro, que intenta tocar las percepciones de aquellos que la observan. Son, en otros términos, obras que pretenden afectar al otro y lo otro, para lo cual ponen en juego, no solamente su mismidad, sino también el adentro y el afuera a partir de la instalación, del material, del color y del juego de luces y sombras, elementos que la constituyen como un acontecimiento.

Ahora bien, al decir que la obra de arte constituye un mundo se hace referencia a que en ella, en la obra, se evidencia aquello a lo que los individuos están sujetos, ligados inseparablemente, aquello que los define. En otras palabras, en la obra de arte se expone el mundo construido por los significados de aquel que ha tenido y vivido una experiencia. En esta medida, los objetos del mundo presentes se constituyen en un haz de relaciones, adquieren sentido en su posibilidad relacional, evidenciando un tiempo, unos espacios en los cuales los diversos objetos adquieren sentido. Lo anterior no significa que la obra de arte sea en sí misma una narrativa, sino que es contenedora y posibilitadora de ellas, lo que permite extender los contornos de diversos relatos que devienen de una experiencia vivida.

La obra de arte, entonces, pone al observador frente a otras temporalidades, evidencia el encuentro con diversos pasados y devela formas de futuro. Así las diversas temporalidades y lo recordado, en tanto sentido, coadyuvan a la construcción de un 
campo de significados que se sostiene en el tipo de elementos que se presentan en las obras y las relaciones que en ellas están instituidas. Ahora bien, dichas relaciones van más allá de la obra de arte. Estas emergen en la posibilidad del contexto, en las individualidades y en lo que ella misma contiene en su presencia.

Desde esta perspectiva, la memoria, como elemento constitutivo, se convierte en un dispositivo importante en tanto las construcciones estéticas y simbólicas ponen en disputa la formas en las cuales se vive $y$ se comprende el presente, y a su vez entrevén las formas en que las memorias del hecho social "se imprimen en los cuerpos, en los objetos y en los lugares" (Cortes, 2011, p. 7). Las imágenes expuestas, los objetos significados permiten la elaboración de una percepción del mundo editando, si se permite el término, lo visible y a su vez lo recordable. De este modo lo vivido, la experiencia, como recuerdo, se instala como dador de sentido a lo construido estéticamente, y a su vez como ventana que deja ver lo que ha sido el pasado, las maneras de comprender el presente y de construir horizontes de futuro. De acuerdo a lo anterior, estamos diciendo que la construcción estética acude a guijos de la experiencia vivida en el tiempo, los que articulados de diferentes maneras posibilitan el cuestionamiento de la realidad más allá de las presencias en interacción con el pasado y el futuro (Cortes, 2011).
Afirmamos, de esta manera, que las construcciones estéticas no intentan recuperar el pasado; sin embargo, el recuerdo posibilita la construcción de un marco de sentido que devela la identidad de los sujetos, así como las maneras en que se comprenden y se instalan en el tiempo, lo que coadyuva, en su relación con el transversal presente, a la construcción de nuevas obras estéticas. La memoria, entonces, se constituye en un marco de constitución de sentidos los cuales posibilitan las disímiles comprensiones que tenemos del presente y que se "manifiestan en actuaciones y expresiones que antes de re-presentar el pasado lo incorporan performativamente" (Jelin, 2001, p. 37).

La forma en que algunas obras re-significan, recuperan e incorporan el pasado, el recuerdo, la memoria, permite la elaboración de espacios políticos desde varios vértices. Uno de ellos tiene que ver con lo que ellas, las obras estéticas, agencian. La posibilidad de la obras de arte al instalarse como acontecimientos y no solamente como referencia las configura como espacios políticos, si entendemos la obra como una forma de pensamiento $y$ de conocimiento, es decir, sus lenguajes, estructuras y los disímiles elementos que ellas elaboran no son la emergencia de un ejercicio catártico, son el resultado de una reflexión en torno al presente que se erige desde la experiencia vivida, presentada a través de diversos 
artilugios metafóricos. En este sentido, exteriorizan la otredad, lo disímil, la singularidad.

Dicha otredad, desde la perspectiva de Bal (2010), posibilita el antagonismo, el disenso, la conflictividad, el extrañamiento y por tanto el espacio de lo que llamaríamos lo político y que expresa Chantal Mouffe (2007) de la siguiente manera:

[...] concibo 'lo político' como la dimensión de antagonismo que considero constitutiva de las sociedades humanas, mientras que entiendo 'la política' como el conjunto de prácticas e instituciones a través de las cuales se crea un determinado orden, organizando la coexistencia humana en el contexto de la conflictividad derivada de lo político (p. 16).

Las obras de arte, entendidas como políticas, dejan correr juicios, pues "son lugares donde las sentencias de la justicia y los actos de controversia democrática -aun en silencio, en la forma de pensamiento y deliberación- no son solo permitidos sino activamente habilitados" (Bal, 2010, p. 10).

Desde esta perspectiva, al instalarse la obra de arte en la cotidianidad y al intervenir en ella, se transforma en un espacio de lo político, pues funda espacios que posibilitan la expresión de un otro y desde el cual se evidencia una suerte de extrañamiento frente a la otredad pero siendo parte de ella y componiendo sentidos $-\mathrm{y}$ no solamente significados- que exhortan a contemplar la vida desde un lugar del afuera.

A su vez, podemos entender las obras como conocimiento si comprendemos que ellas son artefactos que permiten pensar la vida y develar una perspectiva sobre ella, es decir, hacen inteligibles diversas formas de comprensión, las ponen en movimiento, en escena, las sitúan, las hacen presentes en un continuo, en una acción que se da en la presencia de la obra de arte, visibilizando las formas de ser de la experiencia, las cuales afectan la subjetividad e inciden en las maneras en que vivimos la experiencia del presente. En este orden, las obras de arte se instalan como acontecimientos que fracturan la percepción en un instante particular, en el momento del observador. Ellas, entonces, movilizan conceptos, formas de pensar que se materializan en la construcción estética. Así, las obras son provocadas "por una forma específica del pensamiento, propiamente estético, que trata de poner en juego las formas de vida del hombre" (Farina, 2005, p. 78), las 
cuales develan lugares de reflexión de los individuos y en las que esta expresa su subjetividad, sus conflictos, sus preguntas, su devenir, su ser del pasado y su estar en el presente. Ello conlleva a la problematización de los espacios del vivir y los modos en que se da la experiencia haciéndola audible, visible.

Las grafías (entendido este término más cercano a formas que a escrituras) de la estética erigen formas de ver y de comprender, enfocan una mirada sobre un acontecimiento, crean un estatuto de la razón que va más allá de la lógica positivista, instalan y configuran un modo de percepción en el que al sentir, como manera de conocer, vuelca la mirada del observador hacia diversas figuras de la comprensión, pone en acción lógicas de significado que intervienen en el mundo del espectador, de sus razonamientos y sus aprendizajes. Funda, para el espectador, un modo y un campo de significación desde el cual ver, sentir y pensar una experiencia.

Tal incidencia en los campos de significación convierte a la obra de arte en un espacio de lo político, no solamente como un espacio dialógico y de visibilización del antagonismo, sino como la puesta en juego de una forma de conocer $y$ ver una realidad. La pintura, el cine, la fotografía están encuadrados en un tiempo y una espacialidad, la cual abre un lugar para la mirada, pero no aquella del ojo que observa, sino del cuerpo que experimenta, pues trae a colación la vivencia del observador y lo pone en tensión con aquello erigido como mundo en la obra de arte en el que se contraen y se relacionan de manera abigarrada memorias, constructos culturales, sociales, económicos y políticos. En otras palabras, la puesta en escena de la obra de arte es la edificación de una mirada sobre la mirada.

Dejar ver, en este sentido, es instalar una visión de un sujeto que aprehende una realidad como acontecimiento trasladando la mirada al estímulo, a la sensibilidad. Así, la estética se entiende como una manera de posicionar un discurso, un saber que se da en la constitución de una sensibilidad, en la institución de un determinado cuerpo, de una determinada forma de percepción, pues no está dada en el ángulo de la mirada, sino en el haz de relaciones que se ponen en juego. La mirada es aquí entendida no solo como el campo de visibilidad, sino que está relacionada con la posibilidad del ver en que deambula la imagen, pues ella integra en sí misma una cadena de significaciones, de reverberaciones que permiten un sentir. La mirada conduce a unas formas de conceptuar, de fragmentar y de mostrar distancias y cercanías, de limitar y de quebrar las maneras en que los sujetos se acercan a la experiencia estética, la cual, no obstante, se tensiona con lo aprendido y lo construido por el observador.

La práctica del observador se da desde una experiencia espacio 
temporal. La observación es también un acontecimiento, se produce, se ejerce una fuerza, un accionar sobre aquello observado. Transversal a ello, la observación y su relación con lo observado, con la obra estética, hace del observador un personaje de la experiencia, pero dicho personaje es apresado por la imagen, es capturada su mirada. El plisado perceptivo del observador es torcido por la imagen, los símbolos y las relaciones que entre estos elementos pone a jugar la construcción estética; ellas elaboran un espacio-acontecimiento que afecta tanto lo aprendido como las tradiciones históricas y culturales del individuo que se encuentra en medio del ser estético y a su vez, su presencia incide en la configuración de la obra misma, la compone en un flujo perceptivo como conciencia de saber, trasportándose a la imaginación que la imagen ha construido. De este modo, la imagen se instaura en un espacio de formación y de construcción de visibilidades, en la que el observador es participante.

Este escenario nos lleva a pensar que la obra de arte funda un espacio de formación, pues hay una afectación de la percepción y del saber (Farina, 2005) que alude, perturba al individuo que ha erigido el espacio de observación. Sin embargo, dicha afectación no es tan solo un episodio individual: tiene relación con una estética colectiva que los sujetos encarnan. Las formas de percepción que inauguran las obras de arte delimitan una espacialidad en la que se mueven los individuos, se juzgan y dinamizan sus concepciones, sus pasados, sus presentes, sus formas de narrarse y comprenderse. Los sujetos edifican una sensibilidad desde las intensidades asentadas en las obras de arte y en los regímenes de percepción que activan, en los que está implícita una forma de humanidad, lo cual sugiere una manera de pensar las relaciones, los tejidos sociales, pues se encuentran en juego unos principios, unas fuerzas que desorganizan o intensifican una sensibilidad, lo cual conduce a compresiones ético-políticas. Recordemos que, en términos generales, "se educa y se aprende a operar en un determinado horizonte de saber que funciona según una composición de fuerzas que edifican la percepción del sujeto" (Farina, 2005, p. 317).

Lo anterior no quiere decir que las imágenes se postulen como los únicos lugares en que se elaboran las formas de percepción de los individuos, pero sí que el arte y sus diversas figuras hoy hacen parte de espacios que se conciben más allá de la representación y suponen una afectación a las maneras en que comprendemos 
la realidad. Los acercamientos que los sujetos tienen a este tipo de experiencia invocan una humanidad, una experiencia en la que las maneras en que los individuos se narran afectan al otro y lo otro, pues la estética habla de las sensibilidades desde las cuales nos edificamos los humanos.

Desde la perspectiva que estamos planteando, la memoria juega un papel fundamental, pero no tanto en el recordar, sino como evocadora y marco de sentido de la experiencia estética que intenta permear $y$ afectar los regímenes perceptivos de los individuos. Es decir, la memoria en tanto constituyente de sentido, involucra ese instante que se encarna en los cuerpos y en las formas del ver y del sentir que no intenta reproducir la obra, pues lo que ella hace es recuperar lo sentido y transformarlo en una formación compleja que da visibilidad a aquello vivido, lo que no indica que lo represente, sino que lo transporta y lo metaforiza en la gama de relaciones que establece para configurar la construcción estética.

A manera de conclusión de esta primera parte, podemos decir que la posibilidad de metaforización y expresión de lo otro vivido y experimentado, la visibilización y escenificación es lo que le permite a la obra de arte ser un espacio de lo político, pues deja ver lo otro, lo antagónico, la disputa y la controversia, viabilizando la emergencia de la subjetividad en el espacio público, quebrando formas de entender, pero a su vez inaugurando y constituyendo formas de percibir las cuales son mucho más que maneras del ver. Desde esta posibilidad y comprensión es que nos acercarnos a la obras de la artista Erika Diettes, en sus trabajos Río abajo y Sudarios.

\section{Río Abajo y Sudarios,} percepciones y estéticas de la violencia

Recordar y relatar lo sucedido, en contextos de violencia como el colombiano, desde nuestra postura, tiene dos aristas. Una de ellas tiene que ver con la remembranza de lo sucedido: se trata de contar los eventos que los sujetos afectados por la violencia han sufrido. Tal remembranza nos ubica en un espacio del decir que aunque nos devela la humanidad, lo atroz y lo terrorífico, nunca nos permite comunicar el significado de la ausencia de los seres queridos, la incertidumbre de no saber si un hijo, un hermano, un padre o una madre están muertos o vivos, y mucho menos nos ayuda a comprender las formaciones ético políticas que construye un individuo que ha presenciado una masacre, un asesinato o ha sido objeto de una tortura. Las rememoraciones, el ejercicio de relatar, nos advierte de lo que sucede pero deja en un espacio vacío en relación al dolor, el cual, en muchas ocasiones, es incomunicable. La otra arista de la memoria tiene relación con la forma en que el dolor hace presencia en el 
recuerdo. En otras palabras, el dolor se vive y es el que permite el agenciamiento de una memoria que se instala en muchas ocasiones en objetos, constructos simbólicos o en metáforas. Estas dos aristas, la remembranza de lo sucedido y el dolor como forma en la que se vehiculiza la memoria, son las que se hacen presentes en la obra de Erika Diettes. En otras palabras, su trabajo nos muestra una narrativa que se hace presencia a través de objetos y a la vez nos permite la evidencia del acontecimiento del dolor en el gesto congelado de las expresiones de mujeres testigos de la violencia.

En este punto, sostenemos que las obras analizadas van más allá de la narrativa y se instalan en la memoria del dolor como un espacio político y formador de una visibilidad que se dirige hacia la subjetividad y la experiencia del acontecimiento. A su vez, creemos que estos espacios se constituyen en un régimen de percepción que se edifica desde el velo de la individualidad, lo cual nos genera preguntas en relación a la comprensión de lo que es el conflicto en nuestro país.

\section{Río Abajo: la presencia de la ausencia}

Río Abajo, como lo señala Carlos Alberto Gonzáles ${ }^{1}$, es una serie bastante compleja, pues se sitúa en el vértice de la obra de arte y la realidad social, entre la estética y la política, entre la fotografía como imagen artística y la fotografía como documento (González, 2010). La obra es el resultado de una compleja investigación y un recorrido por la geografía de la violencia rural y urbana de Colombia, buscando y encontrando las víctimas de la guerra e indagando en sus recuerdos.

En el caso de Río Abajo, lo que motivó inicialmente a la artista fue el informe especial del diario El Tiempo acerca de la exhumación de fosas comunes de los paramilitares, "Colombia busca a 10.000 muertos $^{\prime 2}$

Colombia busca sus muertos era un editorial de El Tiempo muy fuerte, de hace como dos años; la página fue diagramada con unos huesos y unas botas en la mitad muy grandes y a los lados prendas de ropa tal como se encontraban en las fosas. Esto hizo click en mi cabeza, pues lo relacioné con aquellas prendas en el agua que tenía guardadas, en un proceso que como artista es 
importante pues las imágenes construyen imágenes. Así que decidí que quería buscar prendas de gente desaparecida $y$ fotografiarlas en el agua, como una analogía a los ríos de Colombia que se llevan los cadáveres de la violencia aguas abajo. Esto fue como el primer inicio de este trabajo (CaIle, Diettes, 2008).

Su estrategia se concentró, entonces, en detectar personas con una experiencia directa con la muerte o desaparición de seres queridos; los conoció, visitó y entrevistó para finalmente persuadirlos y lograr que se desprendieran, temporalmente, de una prenda de la víctima para fotografiarla. Emperatriz de Guevara, madre del mayor Julián Ernesto Guevara $^{3}$, fue la primera persona que accedió a participar del proyecto de Erika. El paso siguiente sería el arribo de Diettes al medio oriente antioqueño, donde se encontraría con un grupo de mujeres víctimas de la violencia o en proceso de duelo y asociadas a diferentes organizaciones ${ }^{4}$.

3 Policía colombiano secuestrado durante la toma de Mitú por parte de las Fuerzas Armadas Revolucionarias de Colombia (FARC), el 1 de noviembre de 1998. Guevara murió en cautiverio a finales de enero de 2006, a los 41 años de edad. Hasta hace poco, este grupo insurgente se negaban a entregar el cadáver a sus familiares; sin embargo, las FARC entregaron los restos a la senadora Piedad Córdoba y a la madre del oficial el 1 de Abril, 2010

4 Estas organizaciones son: el Cinep, el Programa por la Paz y el trabajo con Amor o la Asociación de mujeres del oriente antioqueño y la Asociación de Promotoras de Vida y Salud Mental de Marinilla.
Yo me puse a mirar cómo la gente lloraba. Cómo en ese dolor...hay un punto donde no hay lágrimas. Donde el Ilanto es más interno que las lágrimas. En ese momento decidí que no quería fotografiar el dolor como tal sino la pausa del dolor... Me obsesioné por generar en imágenes ese "silencio del dolor ". No sé, yo insistía en que la imagen de alguna manera fuera tangible. Que fuera como escuchar ese dolor. En los muchos viajes que hice al oriente antioqueño buscaba la liberación de ese Ilanto. Y liberarlos a ellos mismos de esos recuerdos y memorias... como dejarlos ir en paz (Calle, Diettes, 2008).

Posterior a este encuentro, Erika recopila alrededor de 150 objetos pertenecientes a víctimas de la desaparición forzada y trabaja con ellos bajo la premisa "los ríos colombianos son el cementerio más grande del mundo", lo cual alude a una práctica común de los grupos armados: arrojar a sus víctimas a los caudales de los ríos como estrategia para ocultar las huellas de la muerte, el asesinato e incluso los individuos:

Una de las formas de evasión que se propician con las víctimas es el abandono 
de los cuerpos en los grandes ríos y en los mares del país. Ese destino fluvial es una forma de quitarle identidad a los muertos y también una manera de atomizar los tabulados que se puedan hacer sobre los mismos. Es un esfuerzo por borrar los hechos y dejar a la corriente la desintegración de los testimonios del delito. Entonces el agua se convierte en un escenario macabro dislocando todos sus significados que la señalan como fuente de vida, vehículo de prosperidad, garantía de subsistencia y agente de fecundidad. Al negar estas características los torrentes caudalosos se convierten en agentes de impunidad y en paisajes macabros que hacen circular la muerte (González, 2010).

Así emerge Río Abajo, serie compuesta por imágenes translúcidas, casi fantasmagóricas, donde se presentan objetos flotantes en aguas cristalinas, prendas que estaban listas para vestir al esperado que nunca llegó. Los objetos, vehículos de la memoria, flotan en una especie de agua pura, limpia. Se instalan en fotografías impresas sobre cristales cuyas dimensiones cercanas a las del cuerpo humano representan la presencia de la ausencia.

Después de tener estas primeras imágenes sentí la necesidad que el proyecto fuera transparente. A medida que me encontré con sus elementos entendí que lo que estaba fotografiando era el retrato de un fantasma. Y llegué a la idea de que las imágenes tenían que ser impresas sobre vidrio. (Calle, Diettes, 2008).

Las imágenes que componen la serie se vieron por primera vez en la Casa de la Cultura de Granada, medio oriente antioqueño, en 2008, en plena "Jornada de la luz"5. La obra de Erika abriría campo a una experiencia estética impactante y a un complejo ritual donde el duelo, la memoria, la narración y el dolor, como el trayecto de un río, fluirían en un intento por rescatar del oscuro pozo del olvido a los sin voz, a las víctimas. Imágenes de prendas suspendidas en agua, eso es Río Abajo, un complejo relacional, pues cada objeto que la compone contiene el peso de las vivencias a las que alude, la carga de aquello que corre por los ríos colombianos, que como venas han nutrido su historia y su memoria. 
Uno de los elementos más complejos simbólicamente en esta serie es el agua, ya que lejos de su estado natural se convierte en receptáculo, en continuidad estática, en metáfora de aquello que espera en silencio, en trayecto, en camino y estancia. Agua transparente, iluminada, sosegada, diáfana, que aunque visible no lo es por sí misma, sino con la ayuda de un color ajeno que permanece suspendido, flotante, inmerso en la complejidad temporal de lo inmaterial, de lo efímero, de lo evanescente, de lo espectral, como advenir del acontecimiento.

Las prendas y objetos narran la historia de alguien, de una vida, un gusto, una personalidad, una labor, son la memoria viva de aquel que ya no está, son las huellas que permanecen, que resisten, son el rastro y el rostro de quien partió de forma violenta, repentina y que aún es aguardado. Las prendas hechas imagen en Río Abajo son mucho más que simples prendas: han sido conservadas, atesoradas por las familias a manera de lazo, de puente entre la vida y la muerte, que a pesar de mantener, algunas, los rastros de los proyectiles, consiguen restituir de una $u$ otra forma al ser ausente, al cuerpo que les fue arrebatado violentamente.

Contraria a la violencia de los actos de los cuales son testigos las prendas que presenta la serie, la obra está llena de serenidad, de un silencio sobrecogedor que pareciera devolver la tranquilidad a los ausentes, brindando cierto alivio a quien la observa, pero también interroga, sacude, conmueve, exhorta. Río abajo logra, a pesar de que el lugar donde se exponga varíe, conectar la memoria de un dolor colectivo con la memoria de un dolor particular, singular, que devuelve la humanidad, la magnitud, la trascendencia a un fenómeno que poco a poco se ha "integrado" al diario vivir, desdibujándose en estadísticas y reportajes noticiosos esporádicos.

La serie, surgida del trabajo con pobladores del medio oriente antioqueño, ha sido expuesta en muchos de sus municipios ${ }^{6}$, y aunque en ellos las imágenes son presentadas en un formato más pequeño que en las galerías, la fuerza de las imágenes hace que salten del cristal y se presenten ruidosas, majestuosas, pero a la vez ligeras y efímeras al ser iluminadas con cientos de velas blancas que inundan con un sentido ritual el montaje. Iglesias y casas de cultura se han convertido en escenarios para la puesta en escena de Río abajo por ser lugares no solo de encuentro y de identidad colectiva, sino testigos de la tragedia, el dolor y la muerte e incluso lugares de reconciliación y ritual que ahora se convierten en ríos donde los moradores de los municipios han podido ver de nuevo a los hijos, nietos, esposos, vecinos y amigos ausentes y han tenido, de alguna manera, un cuerpo del cual despedirse, al cual Ilorar.

6 Algunos de ellos son Granada, La Unión, Cocorná, El Peñol, Calmen de Viboral y Guarne, en Antioquia. 


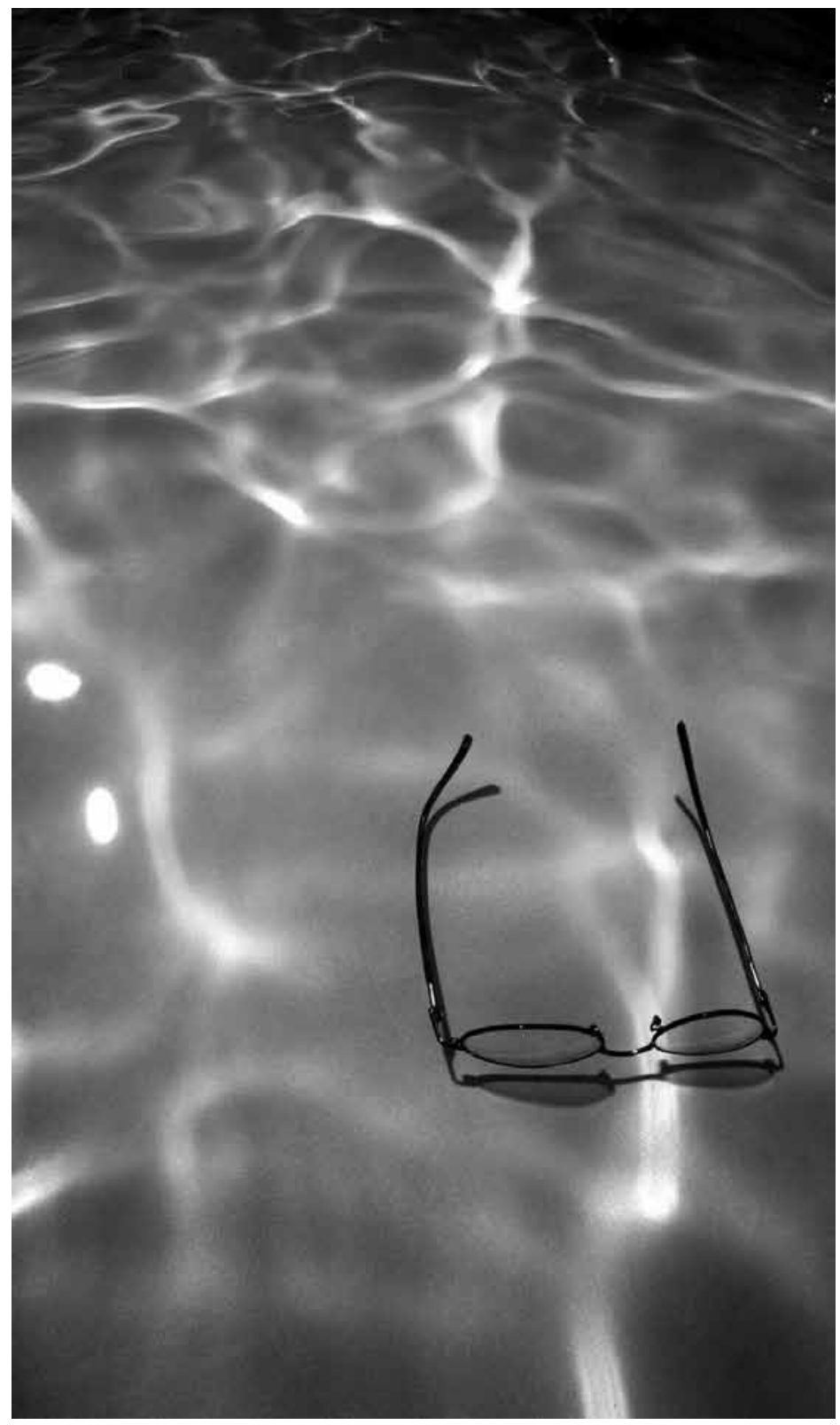

Erika Diettes. De la serie Rio Abajo $(2008)^{1}$

1 Las fotografías aquí expuestas cuentan con la autorización de la artista plástica Erika Diettes para su publicación. 
Lejos de las calles de los municipios antioqueños, en las ciudades de nuestro país, la serie también se ha abierto espacio habitando galerías, universidades e incluso lugares como el Palacio de la Inquisición en Cartagena, tomando en cada uno de ellos una connotación diferente, donde no hay procesión ni velas, pues no hay "jornada de la luz", sino un río inmenso, constituido por imponentes imágenes que sumergen al espectador en las aguas de la memoria, en el encuentro con las voces de los acallados, de los desaparecidos en los ríos colombianos. En dichos lugares, las fotografías de la artista Erika Diettes parecen cajones mortuorios, sepulturas que transforman cada lugar que habitan en campos santos, pero que a la vez aluden a un movimiento perpetuo, un fragmento de tiempo detenido pero no estático, un relato silencioso de una tragedia que pide a voces justicia; sin duda una experiencia conmovedora, inquietante, que interpela desde lo sensible, pero que a su vez permea las capas de lo político y lo ético.

De esta manera, la obra de Diettes logra no solo crear imágenes artísticas, sino abrir un espacio para el duelo, un lugar de ritualización y de memoria que interpela al espectador, haciéndolo por un momento parte de ese río interminable donde las voces de aquellos que ya no la tienen emerge desde lo profundo, narrando la historia de un país que prefiere olvidar para no pensar.
Cada una de las fotografías que compone Río Abajo constituye una ruta por los recuerdos de los otros, esto es, la serie va abriendo un trayecto sinuoso y entretejido por una suerte de resonancias a través de los recuerdos de los ausentes; la presencia de aquellos que no están. Sin embargo, el observador solo ve la huella en el presente. Las imágenes no despliegan lo que podríamos llamar una narrativa, pero entonces ¿qué posibilita que nos liemos al dolor de la ausencia?, ¿qué permite que suframos y observemos el dolor y no solo el objeto?, ¿cómo constituimos una serie de sensibilidades frente al dolor de lo otro?, ¿qué hace que esta obra se piense como un espacio de lo político, y a su vez como un espacio de formación?

La obra de Erika Diettes es un acontecimiento. Cada uno de los elementos que componen la fotografía va presentando una serie de significados que entrelazados constituyen el sentido de la obra. Lo anterior hace que se genere un movimiento de tensión entre aquello que hace presencia y la descarga de la imagen haciendo que el espectador la sufra. Cada elemento es un campo semántico detonador de significados, lo cual hace que el espectador no vea, en este caso particular, una prenda de alguien, sino todo su entramado significacional. Quizás por ello, la imagen no representa, conlleva al dinamismo que atrapa al espectador. Este movimiento hace que la mirada del espectador quede 
capturada en la mirada construida por la obra, donde se edifica un mundo que emerge de las resonancias de lo vivido.

Allí, en esa visibilidad de la no presencia es que se conforma el espacio de lo político, pues la voz del muerto, del desaparecido, se deja escuchar, es la visibilización de lo invisible. El sufrimiento, la ausencia, cobra un valor, instituye una sensibilidad que es puesta en escena, edifica un escenario de mirada a lo otro, un espacio de percepción en el que la individualidad constituye la escena. $Y$ es esa individualidad la que permea la presencia del observador en un espacio de lo público. Elemento fundante de lo político, en otras palabras, es la enunciación de lo vivido como dolor y como testimonio, es la voz de la subjetividad la que hace presencia desde su posibilidad enunciadora, la que pone en cuestión las formas en que constituimos nuestros tejidos sociales y nuestra subjetividad.

En este sentido, la vivencia de lo sufrido, la rememoriación del otro y de su situación, la del muerto, la del desaparecido, irrumpe desde la memoria que comprime todo un contexto, toda una situación que deviene del pasado y permite la presencia en la perfomatividad de la obra y en el complejo simbólico que ella construye. Es decir, pone de presente la conflictividad social de nuestro país encarnada en la desaparición de unos sujetos que más allá de ser enunciados por sus nombres, ahora son presentados como fantasmas que recorren los ríos de nuestro país y las memorias de aquellos que han tenido que vivir su desvanecimiento.

Para aquellos que han tenido la posibilidad de vivir la instalación completa de Río abajo, el recorrido por la misma se asimila al llevado a cabo por un cementerio. Los recuerdos de las víctimas se encuentran contenidos en una suerte de lápidas, las cuales se observan a través del ondulado trayecto elaborado por la forma en que está organizada la obra. Sin embargo, las lápidas no nominalizan a un sujeto, sino a lo que era su presencia a través de cada uno de las prendas que dicen quiénes eran -unas gafas, un jean agujereado, un bolso, unas botas, una camiseta etc.-. El observador no se encuentra observando la obra, sino un evento, un acontecimiento, una memoria, una percepción.

El observador se introduce en una suerte de ritual en el que su observación se ve incidida por las formas del ver que constituye la obra. La obra y su instalación inauguran una comprensión de nuestra violencia. Nos hace visible la violencia, ya no desde sus 
causas o efectos, desde las fuerzas en pugna, sino que ubica a los individuos, su presencia y sus memorias en el mismo lugar. No son las contradicciones y los enfrentamientos, no son las tensiones y las luchas por el poder lo que se quiere develar, es la desaparición de la existencia. Tal vez por ello la diversidad de personajes es posible, pues el dolor no tiene una mancha partidista, se desancla de un color político y tampoco adquiere, ninguno de los personajes, el lugar de victimario o contradictor, lo cual no sugiere una posición apolítica de la obra.

Esta forma de percibir el mundo vivido es el lugar en el que se introduce el espectador. Esta manera de ver la violencia es una forma de conocerla y comprenderla. Es una perspectiva que complica e incide en aquel que mira la obra, constituyéndola desde la sensibilidad. Tal perspectiva se instaura desde un discurso que posibilita la observación y el acercamiento al otro y que instaura una ética que evidencia el sin sentido de la violencia y permite entrever una política desde la presencia de lo sentido. La obra reubica la violencia, habla de los sujetos desaparecidos y diagrama una manera de pensar la violencia, un modo de ser ante ella desde las intensidades de las experiencias individuales y colectivas, presentándose, entonces, la obra de arte como una reflexión ante la vida y la cual supone su intención de transformarla.

\section{Sudarios: cuando el dolor se}

\section{hace presencia}

A partir de la idea de capturar el silencio, la ausencia y el dolor en imágenes nace Sudarios (2011), la más reciente obra de Erika Diettes. Es una serie en la que se presentan, sobre telas muy finas que penden de hilos casi imperceptibles, los retratos de veinte mujeres, todas ellas testigos de lo que la artista describe como algunas de las formas más crueles de violencia: tortura, violación, mutilación y asesinato de sus seres queridos.

El surgimiento de Sudarios está ligado estrechamente al proceso de construcción y exposición de Río abajo, ya que en medio de él, la artista se da cuenta de que en los relatos de las personas había una constante: los victimarios creaban un público para sus violencias como si se tratara de un espectáculo teatral. Entonces, mientras llega el fin de quienes morían, los que quedan se ven obligados a vivir con imágenes cargadas del dolor de los otros y de su imposibilidad de hacer cualquier cosa. Diettes decide, entonces, capturar con su cámara el gesto del rostro de las mujeres al narrar, al recordar las imágenes de lo presenciado, de lo vivido. 

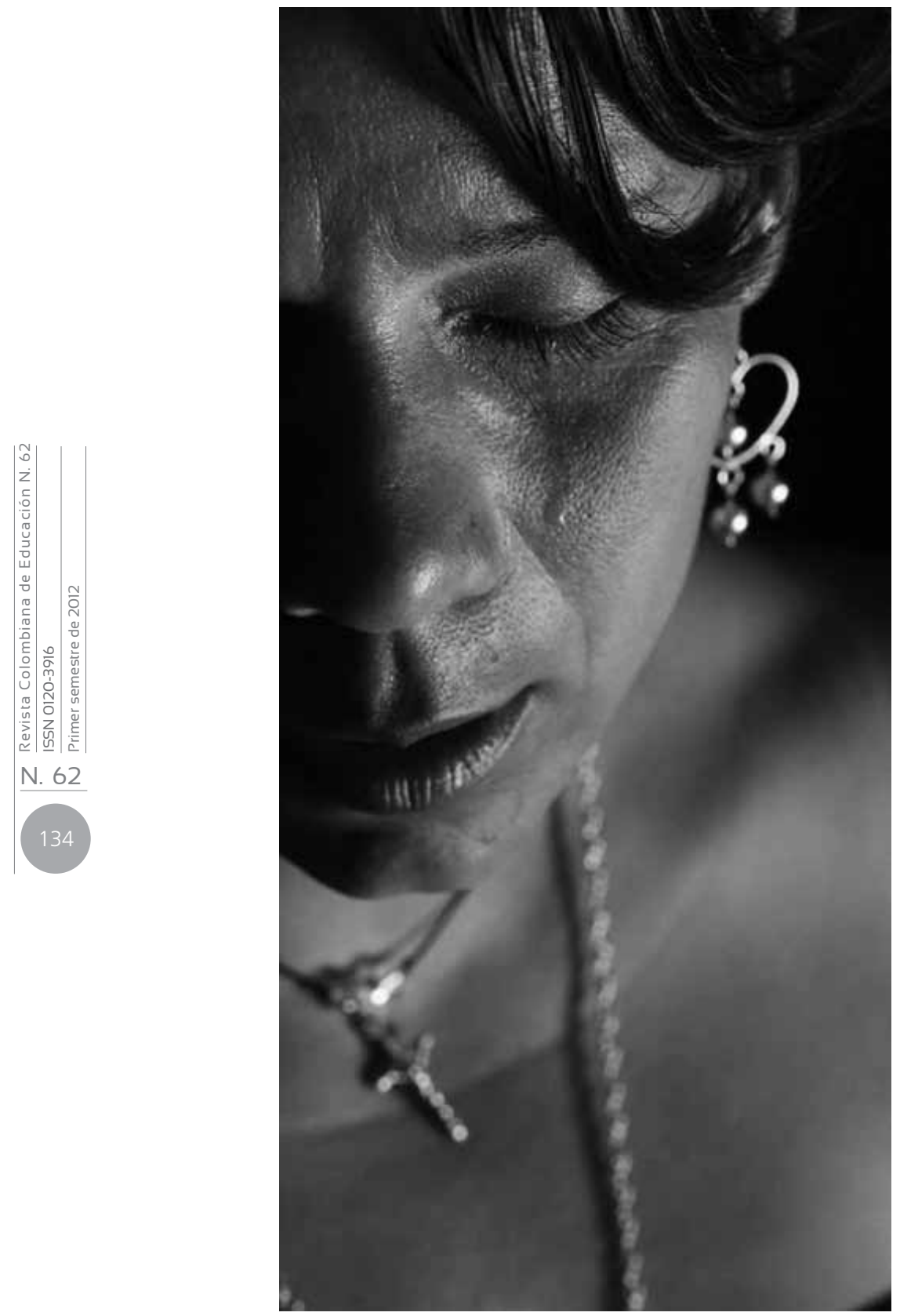
En compañía de las organizaciones con las cuales había desarrollado trabajos anteriores, Erika acude a las mujeres, pues son ellas en las que recae el peso de la memoria por ser sus hombres quienes, en la mayoría de las ocasiones, sufren la muerte violenta. Mientras las espectadoras del dolor, en el fuerte sentido de la palabra, acceden a relatar su sufrimiento, seguidas por un equipo de apoyo psicológico y Erika como acompañante y escucha, van desnudando lo sentido. Ellas, las dolientes, con el dorso descubierto, un poco insinuado por la artista plástica, dejan salir palabras, lágrimas y gestos irrepetibles causados por el dolor y el recuerdo, allí se da la imagen, ese momento en que el dolor se vuelve cuerpo: Sudarios.

Así, el asunto de representar lo efímero se hacía presente, es allí que la artista decide dar forma a las imágenes sobre delicadas telas de seda algodón que hacen las veces de sudario, símbolo de la muerte, del dolor, de la soledad, pero también de la resurrección y del triunfo, donde, como en el caso de la pasión de Cristo, quedaría plasmado el rostro de aquel en padecimiento. El lugar elegido para presentar por primera vez la serie fue el Museo Iglesia Santa Clara de Bogotá, ubicado muy cerca al palacio presidencial y que antiguamente solía ser un convento de mujeres, y en el que bajo la custodia de un dorado imponente, reposan numerosas imágenes de santas y mártires de los tiempos co- loniales, cargando así la obra de un simbolismo casi mítico.

La experiencia del espectador frente al trabajo de Diettes fluctúa entre lo onírico y lo real, entre un presente y un pasado que comparten la vivencia del dolor y la muerte en donde veinte mujeres son elevadas a la posición de aquellas que reposan como mártires en las paredes del antiguo templo.

El color de las imágenes en Sudarios refuerza esa idea de lo histórico, de lo ligado a la memoria, en tanto que el blanco y negro han sido la paleta de color en la memoria visual de muchos acontecimientos históricos, dotando de cierta sensación de perduración temporal, eternidad y dramatismo a las imágenes. De la misma forma que en Río abajo, el gran tamaño de las imágenes es fundamental en la experiencia del espectador frente a la obra, ya que este genera un impacto visual muy fuerte y la posibilidad de -gracias a la disposición de las fotografías- hacerse uno con la pieza, integrarse a ella. De alguna manera, al recorrer la obra, el movimiento de las telas, la potencia de los gestos fotografiados dejan la sensación de que el dolor abraza al espectador.

Rostros inmensos, ojos cerrados, lágrimas que ruedan por los rostros femeninos del dolor no permiten un observador pasivo: siguiendo la línea de trabajo de la artista, interpelan, cuestionan acerca de las consecuencias que para los seres humanos tiene la vivencia de la violencia, 
cuentan lo que las palabras ocultan, se hacen memoria en medio de un silencio elocuente que guarda, como en los retratos póstumos de las mártires, ese último suspiro, como si las lágrimas, el sudor y la sangre se hubiesen encargado de dejar su testimonio sobre las fibras de las telas.

Sudarios se convierte en un espacio de reverberación del dolor en el que, a diferencia de Río Abajo, la memoria no se juega por la presencia de la ausencia, sino que en ella el dolor quiere ser gritado, visibilizado, presenciado. El recuerdo de la violencia está aquí como causante del dolor, es el metarelato que contiene la obra pero que no hace presencia en ella. La subjetividad, con su sensibilidad, cobra existencia ante el otro que mira. Es la intensidad la que permea y afecta aquel que se acerca a la construcción estética haciendo presente a los sujetos, a las mujeres que tuvieron que vivir y presenciar las escenas de la violencia. El trabajo artístico reconstruye una escena no vista, lo que conduce a afrontarla por lo menos desde el dolor del otro. De este modo, la obra recompone las fuerzas y las intensidades que arreglan los hechos de la violencia y que los sujetos advierten como sensaciones (Farina, 2005).

La potencia que evidencia esta obra de Diettes, reconfigura la mirada, pues no se trata de lo que el ojo hace, sino que lo convierte en una suerte de cuerpo que se transforma en receptáculo de lo sensible. Desde esta perspectiva esta obra no es una representación sino un agenciamiento, pues devela y hace existir la experiencia.

Este giro de la mirada, de nuevo, al igual que en Río abajo, pone en el escenario lo sentido, la individualidad y la subjetividad, pero ahora se trata de la reconfiguración de la memoria, ya no desde lo sucedido, sino de lo experimentado. Situación que afecta a los sujetos y sus percepciones de la violencia, pues lo vuelca al dolor, a la individualidad, flexiona la mirada y la subjetividad hacia aquel que queda, que vivió y que aún subsiste con aquello que quisiera, quizás, olvidar. A las mujeres de Sudarios, como a tantas otras víctimas de la violencia en nuestro país, no es preciso decirles que es necesaria la memoria porque ello ha signado de manera definitiva su cuerpo y sus formas de sentir y de vivir. Quizás para ellas lo necesario es el olvido, olvido que solo llega, seguramente, con la muerte, ya que el instante del dolor ocupa el rostro, los ojos, la mirada, la piel, el gusto con los cuales viven el día a día. 
La obra sugiere una percepción de la violencia desde una arista que trasgrede aquella razón que intenta explicarla, enunciarla y describirla. Es un saber de la violencia que intenta trasladarlo al tiempo y espacio de los individuos afectados, que los acerca a lo no dicho y que refiere a otros modos de sentir.

Es esto lo político de Sudarios, pues traslada la violencia no a un problema de sus consecuencias sino al de sus sentidos, no a los porqué de la misma, sino a sus presencias en el presente, no al valor $y$ a lo invertido sino a las formas en que se encarnan en los individuos y es esta misma percepción la que se intenta formar en el espectador, es decir, la focalización hacia el dolor de las víctimas, ese instante de silencio, ese suspiro frente a lo acontecido.

Pese a lo anterior, ello no nos resuelve por qué en un país como el nuestro hemos llegado hasta aquí, por qué se da nuestra violencia, por qué la permitimos. A su vez nos lleva a plantear que es necesario tanto olvidar como recordar, pero también se hace necesario y urgente comprender.

\section{Unas últimas palabras}

Los acercamientos que hemos intentado a la obra de Erika Diettes nos plantean la necesidad de reflexionar acerca de las maneras en que construimos nuestras memorias, lo que ellas conllevan, su incidencia en los regímenes de visibilidad y los significados que despliegan en tor- no a la violencia. A su vez, nos ayuda a comprender las obras de arte como espacios de formación que coadyuvan a la construcción del ver de sujetos individuales y colectivos. El acercamiento construido nos permite decir que recordar está íntimamente ligado a la configuración de espacios de lo político en los que la voz del otro se dignifica y nutre la conflictividad como espacio democrático. Al tiempo nos permite decir que la estetización de la memoria está imbricada en la presencia de aquello invisibilizado, lo cual supone comprender que otras formas de lo político, del saber y la razón también son dables.

Ahora bien, la percepción construida por la obra de arte, por lo menos las aquí analizadas, se fundan sobre el estadio del dolor y de la individualidad, necesario en un país como el nuestro, el cual, al parecer, se ha construido inerme, en muchos casos, frente al padecimiento del otro. Sin embargo, estas formas de constitución de memorias políticas también nos debe posibilitar comprender los acontecimientos, los tejidos, los sinuosos trayectos y recorridos que hemos seguido para que las diversas violencias políticas se encarnen en formas de masacres, desaparecidos, secuestrados y se hagan presentes en nuestra piel, en nuestros amigos, en nuestras comunidades. 


\section{Referencias}

Arango, D. (2004). Otras Miradas. Colombia: Ministerio de Relaciones Exteriores. República de Colombia.

Bal, M. (2010). Arte para lo político. En: Estudios Visuales, № 7, pp. 39-66.

Blair, E. (2005). Muertes violentas Teatralización de exceso. Colombia: Editorial Universidad de Antioquia, Colección Antropología.

Calle, J., Diettes, E. (2010). Río Abajo. En: Tertulias fotográficas. http://www.fotografiacolombiana.com/erika-diettes-rio-abajo/.Consultado Mayo 26 de 2011.

Cortes, S. C. (2011). La ruina como aproximación estética, política y ética a los escenarios de memorias de la violencia En: Revista Lindes, Estudios sociales del arte y la cultura, N 2, julio, Buenos Aires, Argentina.

Farina, C. (2005). Arte, cuerpo y subjetividad. Estética de la formación y pedagogía de las afecciones. Barcelona: Universitat Barcelona. Tesis Doctoral.

Gonzales, C. A. (2010). Erika Diettes / Río Abajo. En: Fotografía Colombiana. Blog, fotografía y arte. http://www.fotografiacolombiana.com/rio-abajo-erika-diettes/. Consultado mayo 24 de 2011.

Mouffe, C. (2007). En torno a lo político. Buenos Aires: Fondo de Cultura Económica.

Jelin, E. (2001). Los trabajos de la memoria. España: Siglo XXI editores.

Uribe, M. V. (1999). Desde los márgenes de la cultura. En: Museo de Arte Moderno. Arte y violencia en Colombia desde 1948, Bogotá: Norma. 